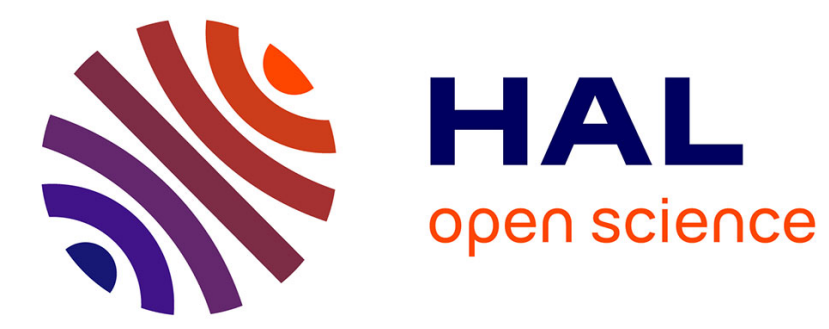

\title{
THE ELECTRICAL AND OPTICAL PROPERTIES OF SODIUM GERMANATE GLASSES
}

\author{
M. Khan, E. Khawaja
}

\section{To cite this version:}

M. Khan, E. Khawaja. THE ELECTRICAL AND OPTICAL PROPERTIES OF SODIUM GERMANATE GLASSES. Journal de Physique Colloques, 1982, 43 (C9), pp.C9-319-C9-322. 10.1051/jphyscol:1982959 . jpa-00222488

\section{HAL Id: jpa-00222488 https://hal.science/jpa-00222488}

Submitted on 1 Jan 1982

HAL is a multi-disciplinary open access archive for the deposit and dissemination of scientific research documents, whether they are published or not. The documents may come from teaching and research institutions in France or abroad, or from public or private research centers.
L'archive ouverte pluridisciplinaire HAL, est destinée au dépôt et à la diffusion de documents scientifiques de niveau recherche, publiés ou non, émanant des établissements d'enseignement et de recherche français ou étrangers, des laboratoires publics ou privés. 


\title{
THE ELECTRICAL AND OPTICAL PROPERTIES OF SODIUM GERMANATE GLASSES
}

\author{
M. N. Khan and E. E. Khawaja \\ Department of Physics, University of Petroteum and Minerals, Dhahran, \\ Saudi Arabia
}

Résumé.- On a mesuré la conductivitê électrique d'une série d'échantillons du systême $\mathrm{Na}, \mathrm{O}-\mathrm{GeO}_{2}$ depuis $1^{\prime}$ ambiante jusqu'à $350^{\circ} \mathrm{C}$. Les résultats sont interprëtés en termes de gaps êlectriques qui décroissent linéairement avec la teneur en $\mathrm{Na} O \mathrm{O}$ des verres: Les seuils d'absorption ont été mesurés et analysés en termes de transitions indirectes à travers un gap optique qui crô̂t également linéairement avec $\mathrm{Na} O$. Cependant, on a trouvé que le gap optique est environ le double du gap électrique correspondant.

Abstract. - The electrical conductivities of a series of specimens in the system $\mathrm{Na}_{2} \mathrm{O}-\mathrm{GeO}_{2}$ were measured at temperatures ranging from room temperature to $350^{\circ} \mathrm{C}$. These results are interpreted in terms of electrical gaps, which decrease 1inearly with the $\mathrm{Na}_{2} \mathrm{O}$ content of the glasses.

Theix absorption edges are measured and analysed in terms of forbidden non-direct transitions across an optical energy gap which is also found to increase linearly with the $\mathrm{Na}_{2} \mathrm{O}$ content of the glasses. However, the optical gap was found roughly to be twice the corresponding electrical gap.

1. Introduction. - The conductivity of glasses and amorphous films has been the subject of an extremely wide range of experimental and theoretical studies (1-4). It is clear even with materials devoid of long range order and with band tailing beyond the normal conduction and valence bands a forbidden gap exists and may be estimated from measurements of electrical conductivity as a function of temperature as well as from optical absorption measured as a function of photon energy.

In the present work the results of conductivity measurements with varying $\mathrm{Na}_{2} \mathrm{O}$ content in the system $\mathrm{Na}_{2} \mathrm{O}-\mathrm{GeO}_{2}$ are reported. As the $\mathrm{Na}_{2} \mathrm{O}$ content is increased the value of activation energy and hence the electrical gap decreases accordingly.

The optical absorption in the specimens was carefully measured. An analysis of the absorption near the absorption edge is presented and discussed in terms of a Davis and Mott. (5) model of the energy levels in amorphous materials. The optical energy gap also decreases 1inearly with the increase in $\mathrm{Na}_{2} \mathrm{O}$ content.

2. Experimenta1.- The raw materials used for the preparation of the glasses were reagent grade $\mathrm{Na}_{2} \mathrm{CO}_{3}$ (as a source for $\mathrm{Na}_{2} \mathrm{O}$ ) and $\mathrm{GeO}_{2}$, both of purity $99.99 \%$ and were supplied by Fisher Scientific Company. The glass batch (compositions are given in table-1) was melted in platinium crucible using an electric furnace at temperatures from $1200^{\circ} \mathrm{C}$ to $1250^{\circ} \mathrm{C}$ for three hours depending upon the composition. The molten glass was casted on a stainless. steel surface in the form of circular pallets of diameter $1 \mathrm{~cm}$. For each composition more than two specimens were casted which varied in thickness from $2 \mathrm{~mm}$ to $5 \mathrm{~mm}$.

The glass samples were polished using diamond-paste down to minimum grit sjze of $0.1 \mu \mathrm{m}$. Due to hygroscopic nature of germanium dioxide glass, acetone was used 
in the process of polishing. Gold was evaporated onto the faces of the specimen to form a guarded electrode system which consisted of a main electrode of $5 \mathrm{~mm}$ in diameter, a ring shaped guard electrode and an electrode opposite. The temperature of the sample was monitored using a chromel-alumel thermocouple attached to the sample.

For each composition (table 1) the absorbance of two specimens of different thicknesses was measured at nomal incidence using a Perkin Elmer $202 \mathrm{UV} / \mathrm{visibIe}$ spectrometer. Fig.2 is an example of the absorbance curves for the composition $\mathrm{E}_{5}$ and samples thickness $3.30 \mathrm{~mm}$ and $2.09 \mathrm{~mm}$.

Table -1

\section{Chemical Composition, electrical and optical energy gaps}

\begin{tabular}{lcccc}
\hline $\begin{array}{l}\text { Melt } \\
\text { No. }\end{array}$ & $\begin{array}{l}\mathrm{GeO}_{2} \\
\text { con- } \\
\text { tent } \\
\left(\omega t_{0}^{\circ}\right)\end{array}$ & $\begin{array}{l}\mathrm{Na}_{2} \mathrm{Co}_{3} \\
\text { con- } \\
\text { tent } \\
\left(\omega \mathrm{t}^{\circ}\right)\end{array}$ & $\begin{array}{c}\text { Activation } \\
\text { Energy } \\
(\mathrm{eV}\end{array}$ & $\begin{array}{c}\text { Optical } \\
\text { gap } \mathrm{E}_{\mathrm{o}} \\
(\mathrm{eV})\end{array}$ \\
\hline $\mathrm{E}_{0}$ & 100 & 0 & 1.00 & - \\
$\mathrm{E}_{1}$ & 90 & 10 & 0.92 & 3.64 \\
$\mathrm{E}_{2}$ & 85 & 15 & 0.86 & 3.57 \\
$\mathrm{E}_{3}$ & 80 & 20 & 0.80 & 3.48 \\
$\mathrm{~F}_{4}$ & 75 & 25 & 0.74 & 3.41 \\
$\mathrm{E}_{5}$ & 70 & 30 & 0.67 & 3.33 \\
\hline
\end{tabular}

\section{Results And Discussion}

3.1. Time dependence of direct currents.- The time dependence of current at an applied voltage of $30 \mathrm{~V}$ was studied for the specimens of different compositions. The polarization effects were observed and the resistivity of the specimens increased with time. This suggests that the ionic currents are dominant. Dominant ionic currents in $\mathrm{Na}_{2} \mathrm{O}-\mathrm{GeO}_{2}$ glasses has also been reported by Evstropev et al. (6).

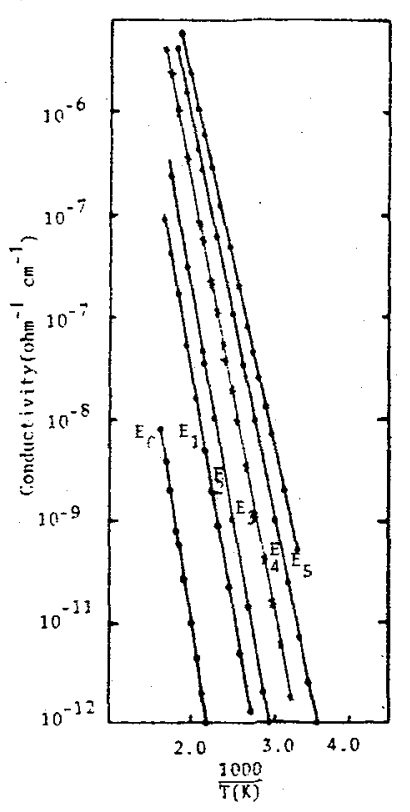

Fig.1: Semilog plots of conductivity versus reciprocal temperature for $\mathrm{Na}_{2} \mathrm{O}-\mathrm{GeO}_{2}$ glasses.

3.2. d.c. conductivity.- Fig.1 shows the plot of logarithmic conductivity against the reciprocal of absolute temperature for a series of glass specimens. In many types of ionically conducting oxide glasses, it is well known that these plots are linear in conformity with the following equation:

$$
\sigma=\sigma_{0} \exp \left(-\frac{\Delta \mathrm{E}}{\mathrm{KT}}\right) \quad \text {. . . . . . . . . . . }
$$

where $\sigma$ is the conductivity $\sigma_{0}$ is a constant for a given glass, $K$ is the Boltzman constant, $\mathrm{T}$ is absolute temperature and $\Delta \mathrm{E}$ is the activation energy for conduction. All the graphs shown here contain straight lines, which are numbered in ascending order as the sodium ion concentration in the specimens increases.

Table 1 lists the derived values of the activation energy and relates them to composition and to the measured values of optical energy gap $\mathrm{E}_{0}$.

A plot of activation energy against $\mathrm{GeO}_{2}$ concentration is shown in Fig.4. It is clear that increasing the $\mathrm{NaO}_{2}$ content causes a decrease in the activation energy for ion transport. At high sodium concentrations, it is easier for the transport of 
mobile ions to take place at given temperature and electric field strength, and hence the increase is equivalent conductance.

3.3. Optical absorption.- Fig.2 shows measurement of absorbance (A) against wavelength for two specimens with same composition $E_{5}$ (table 1 ) and thickness $x_{1}=3.30 \mathrm{~mm}$ and $x_{2}=2.09 \mathrm{~mm}$. The absorption coefficient $\alpha(\lambda)$ which is a function of wavelength $\lambda$ was calculated from the following relation:

$$
\alpha(\lambda)=-\frac{A_{1}(\lambda)-A_{2}(\lambda)}{x_{1}-\bar{x}_{2}}
$$

$\alpha(\lambda)$ was calculated for wavelengths at intervals of $5 \mathrm{~nm}$ from Fig.2. This data was then analysed by the we11 established theory for the absorption in amorphous materials given by Davis \& Mott (5). According to the theory $\mathrm{K}$ - conservation rule breaks down in amorphous materials and $K$ is not a good quantum number. Further, if the matrix element for momentum vector for optical transitions is taken constant (this assumption is valid in the present case as the energy range concerned is sma11) then the absorption can be represented by

$$
(\alpha E)^{\frac{1}{2}}=C\left(E-E_{0}\right) \cdot
$$

where $\mathrm{E}$ is the photon energy and $E_{0}$ is the optical band gap, and $C$ is a constant.

Figure 3 shows plots of $(\alpha E)^{\frac{1}{2}}$ against $E$ for the different compositions of the glasses listed in table 1 . The plots suggest that the absorption follows equation (2). $\mathrm{E}_{\mathrm{o}}$, the band gap for all the compositions studied was obtained by extrapolating the lines to cut E- axis (figure 3). For an example, in the case of composition $E_{5}, E_{0}$ was found to be

$3.33 \mathrm{eV}$ and the corresponding wavelength is $372.4 \mathrm{~nm}$. This

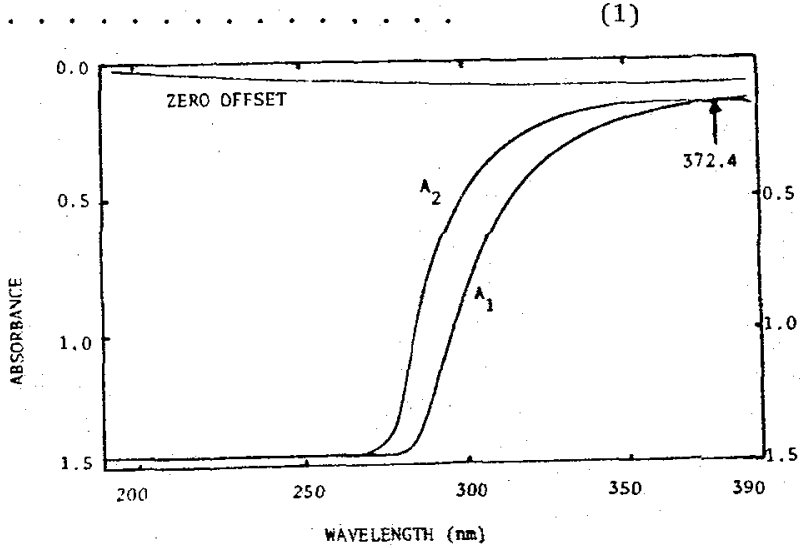

Fig. 2: Absorbance as a function of wavelength for two samples of same composition $E_{5}$ (table 1). Plot $A_{1}$ is for sample thickness $3.3 \mathrm{~mm}$ and $A_{2}$ for 2.09 $\mathrm{mm}$.

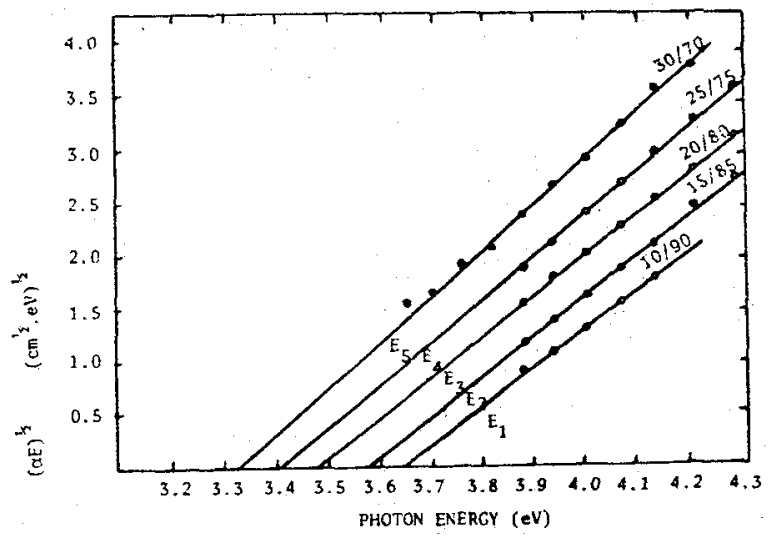

Fig. 3: Plots of $(\alpha E)^{\frac{1}{2}}$ against $E$ for different compositions (table 1 ). value of $\lambda$ is indicated by an arrow in fig.2. Alternately, the absorption edge may be defined as the photon energy at which the absorption starts increasing from the zero value. This is equivalent to saying that the absorption edge is the wavelength at which the curves $A_{1}$ and $\mathrm{A}_{2}$ (Fig.2) start deviating from their constant value. This value lies very close to the value determined from the equation (2) and shown by an arror in Fig.2. A similar agreement was reached in all the five compositions. 
It may be mentioned that in the present work specimens of two thicknesses were studied in order to eliminate refractive index term in the formula for absorbance. otherwise separate measurement for the refractive index was needed.

In Fig.4 $\mathrm{E}_{0}$ is plotted against specimen composition. It is clear that $\mathrm{E}_{\mathrm{o}}$ decreases linearly as the $\mathrm{Na}_{2} \mathrm{O}$ content is increased. $\mathrm{E}_{\mathrm{o}}$ for $100 \% \mathrm{GeO}_{2}$ is estimated to be $3.69 \mathrm{eV}$ in its amorphous state and at room temperature.

4. Conclusion. -The electrical conductivities and optical absorption measurements in the system Na $20-\mathrm{GeO}_{2}$ glasses were carefully made. The values for electrical energy gaps were obtained from conductivity data. The optical energy gaps were determined accurately from the measured absorbance in the specimens of different thicknesses.

It was found that the electrical and the optical energy gap decrease linearly with increasing content of $\mathrm{Na}_{2} \mathrm{O}$ in the glasses. The conductivity increases with increasing $\mathrm{Na}_{2} \mathrm{O}$ content in the glasses.

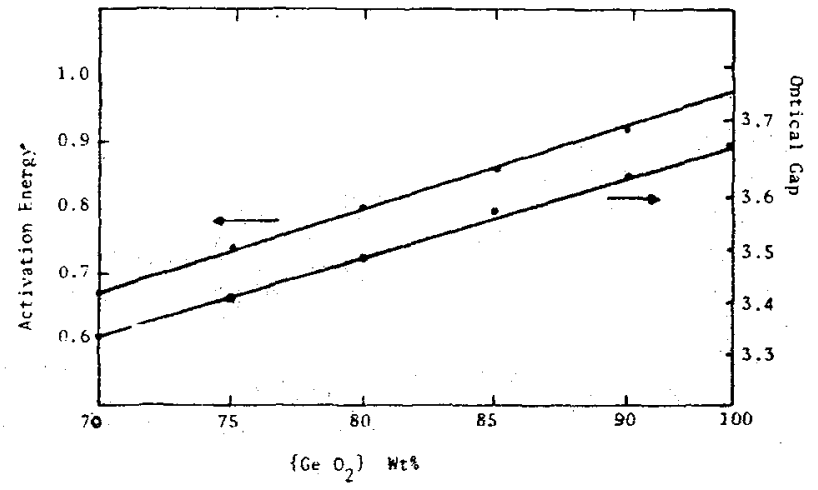

Fig. 4: Dependence of activation energy and optical band gap on glass composition.

The optical absorption in the glasses is analysed in terms of non-direct transitions as formulated by Davis and Mott.

\section{References}

1) Mott,N.F. and Davis,E.A. "Electronic Processes in non-crystalline materials" (Oxford University Press, Oxford 1971).

2) Littleton,J.T. and Morey,G.W. "The Electrical Properties of Glass", Wiley, New York, 1953.

3) Ta1lan,N.M. "Electrical conductivity in ceramics and Glass Part 2", Marce1 Dakker, Inc. 1974.

4) Myuller, Rudol F. "Electrical conductivity of vitreous substances"translated from Russian by Drake,S. and Drake, C.F. Consultants Bureau New York.1971.

5) Davis,E.A. and Mott,N.F. Phil- Mag. 22 (1970) 903.

6) Evstropev,K.S., Pavlovskii,V.K. and Ivanov,A.0. The structure of g1ass, Vo,..4 Ed. O.V. Mazurin Consultants Bureau, New York (1965) 110.

\section{Acknowledgement}

The authors wish to acknowledge gratefully the financial support for this investigation provided by the University of Petroleum \& Minerals' Research Committee. 